\title{
Associação entre a distância percorrida no teste de caminhada de seis minutos e o tempo de internação hospitalar
}

\author{
Association between the distance covered during the six-minute walk \\ test and the length of hospital stay
}

\section{Asociación entre la distancia recorrida durante la prueba de caminata de seis minutos y la duración de la estadía en el hospital}

André Felipe da Silva Correa ${ }^{1}$, Juliana Verdini de Carvalho Pinheiro ${ }^{1,2}$, Vivian Pinto de Almeida ${ }^{3}$, Ricardo de Almeida Gaudio ${ }^{1,4}$, Luciana Moisés Camilo ${ }^{1,4}$, Tiago Batista da Costa Xavier ${ }^{1,4}$, Cristiane Sousa Nascimento Baez Garcia ${ }^{1,4}$, Marco Orsini ${ }^{5}$, Carlos Henrique Melo Reis ${ }^{5}$, Marco Antonio Alves Azizi ${ }^{5}$, Marco Antonio Araújo Leite ${ }^{6}$, Mauricio de Sant Anna $\mathrm{Jr}^{1,4}$

1.Group of Studies in Rehabilitation in High Complexity (GERAC), Rio de Janeiro-RJ, Brazil.

2.Professional Master's Degree Program in Biomedical Research Training, Federal University of Rio de Janeiro (PGPBM-UFRJ), Rio de Janeiro-RJ, Brazil.

3.Physiotherapy Service of Gaffrée e Guinle University Hospital (HUGG), Rio de Janeiro-RJ, Brazil.

4.Federal Institute of Education, Science and Technology of Rio de Janeiro (IFRJ), Rio de Janeiro-RJ, Brazil.

5.Iguaçu University/School of Medicine, Rio de Janeiro (UNIG), Rio de Janeiro-RJ, Brazil.

6. Federal University Fluminense (UFF), Rio de Janeiro-RJ, Brazil.

\begin{abstract}
Resumo
Objetivo. Investigar a relação entre a distância percorrida no teste de caminhada de seis minutos (TC6M) e o tempo de internação dos pacientes internados nas enfermarias do Hospital Universitário Gaffrée e Guinle. Método. Trata-se de um estudo transversal que utilizou uma amostra de conveniência, composta por pacientes com idade superior a 18 anos, entre 20 e 70 dia de internação, com estabilidade hemodinâmica, capazes de deambular. O TC6M foi realizado em um corredor plano, reto, fechado, de 25 metros, com superfície plana e rígida, utilizando comando verbal padronizado. A FC, a $\mathrm{SpO}_{2}$ e a percepção subjetiva do esforço foram verificadas antes, a cada dois minutos durante o TC6M e no primeiro, segundo e terceiro minutos de recuperação. A correlação entre a distância percorrida no TC6M e o tempo de internação hospitalar foi calculada pela correlação de Pearson. Resultados. Foram incluídos no estudo 23 pacientes, 12 homens (52\%) e 11 mulheres (48\%), com média de idade de $58,0 \pm 7,0$ anos e IMC de $23 \pm 0,3 \mathrm{~kg} / \mathrm{m}^{2}$. O tempo médio de internação foi de $12,4 \pm 5,6$ dias e distância média percorrida foi de $406 \pm 55,86 \mathrm{~m}$. Foi encontrada uma associação $(r=0,5234$; $p=0,0104$ ) entre a distância percorrida no TC6M e o tempo de internação. Conclusão. Esses resultados sugerem que os pacientes com maior capacidade de deambulação apresentam menor tempo de internação.
\end{abstract}

Unitermos. Fisioterapia; reabilitação; capacidade funcional

\footnotetext{
Abstract

Objective. To investigate the relationship between the distance covered in the six-minute walk test (6MWT) and the length of hospital stay of patients admitted to Gaffrée e Guinle University Hospital wards. Method. This is a cross-sectional study which used a convenience sample, composed of patients aged over 18 years, between 2 and 7 days of hospitalization, with hemodynamic stability, able to walk. The 6MWT was performed indoor, along a long, flat, straight, enclosed, 25-meter corridor, with a flat and hard surface, using standardized verbal command. $\mathrm{HR}, \mathrm{SpO}_{2}$ and subjective perception of effort were checked before, at every two minutes during the 6MWT and in the first, second and third minutes of recovery. The correlation
} 
between the distance walked on the 6MWT and the length of hospital stay was calculated using Pearson's correlation. Results. The study included 23 patients, 12 men (52\%) and 11 women $(48 \%)$, with a mean age of $58.0 \pm 7.0$ years and a BMI of $23 \pm 0.3 \mathrm{~kg} / \mathrm{m}^{2}$. The average length of stay was $12.4 \pm 5.6$ days and the average distance covered was $406 \pm 55.86 \mathrm{~m}$. An association $(r=0.5234$ and $p=0.0104$ ) was found between the distance covered on the 6MWT and the length of hospital stay. Conclusion. These results suggest that patients with greater walking capacity have shorter hospital stays.

Keywords. Physical therapy; rehabilitation; functional capacity

\section{Resumen}

Objetivo. Investigar la relación entre la distancia recorrida en la prueba de caminata de seis minutos (6MWT) y la duración de la estancia de los pacientes ingresados en las salas del Hospital Universitario Gaffrée y Guinle. Método. Este es un estudio transversal que utilizó una muestra de conveniencia, compuesta por pacientes mayores de 18 años, entre el $2^{\circ}$ y el 70. días de hospitalización, con estabilidad hemodinámica, capaz de caminhar. El 6MWT se realizó en un pasillo plano, recto, cerrado, de 25 metros, con una superficie plana y rígida, utilizando un comando verbal estandarizado. La FC, la SpO2 y la percepción subjetiva del esfuerzo se verificaron antes, cada dos minutos durante el 6MWT y en el primer, segundo y tercer minuto de recuperación. La correlación entre la distancia recorrida en el 6MWT y la duración de la estancia hospitalaria se calculó utilizando la correlación de Pearson. Resultados. El estudio incluyó a 23 pacientes, 12 hombres (52\%) y 11 mujeres (48\%), con una edad media de $58,0 \pm 7,0$ años y un IMC de $23 \pm 0,3 \mathrm{~kg} / \mathrm{m}^{2}$. La duración promedio de la estadía fue de $12,4 \pm 5,6$

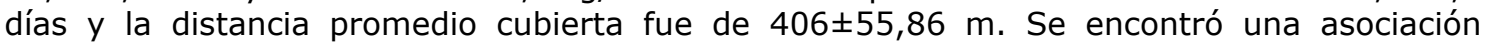
$(r=0,5234$ y $p=0,0104)$ entre la distancia recorrida en el 6MWT y la duración de la estancia hospitalaria. Conclusión. Estos resultados sugieren que los pacientes con mayor capacidad para caminar tienen estancias hospitalarias más cortas.

Palabras clave. Fisioterapia; rehabilitación; capacidad funcional

\section{INTRODUCTION}

Functional capacity can be defined as the physical and mental competencies that an individual need to maintain an independent and autonomous life to perform simple tasks or actions. Therefore, functional disability is defined as the difficulty or impossibility of performing certain activities or basic tasks of everyday life $\mathrm{e}^{1,2}$. 
The Six-Minute Walk Test (6MWT) was proposed for the first time in cardiology by Balke in 1963. Since then, it has been used in several clinical conditions, but still without the proper standardization. In 2002, the American Thoracic Society (ATS) provided practical guidelines for $6 \mathrm{MWT}^{3}$.

According to ATS guidelines (2002), the 6MWT is a simple, practical and low-cost test that aims to evaluate to evaluate functional exercise capacity in submaximal intensity through the distance that an individual can quickly walk, without running or jogging, on a flat and hard surface in a period of six-minute ${ }^{3}$. The 6MWT evaluates the global and integrated responses of the pulmonary, cardiovascular and neuromuscular systems ${ }^{3}$. In addition, 6MWT to presenting a direct correlation with peak oxygen uptake, which is described in the literature as the gold standard for determining aerobic capacity ${ }^{4}$.

Researchers at the National Cardiovascular Center have demonstrated that the distance covered in the 6MWT is strongly associated with mortality in individuals with idiopathic pulmonary arterial hypertension ${ }^{5}$. Other studies have demonstrated the relationship of 6MWT with the prognosis of patients with chronic obstructive pulmonary disease (COPD) ${ }^{6}$ and cardiovascular diseases ${ }^{7,8}$.

Some studies have shown a correlation between functional exercise capacity and length of hospital stay ${ }^{9,10}$. This hypothesis is based on the fact that bed rest during hospitalization reduces cardiorespiratory fitness, leads to loss of peripheral and respiratory muscle strength and 
deconditioning, becoming a risk factor for cardiopulmonary complications ${ }^{11-13}$.

Thus, there is a need for evaluating and monitoring hospitalized patients. In this assessment, an adequate evaluation should be included, emphasizing the ability to walk, once this parameter adequately represents the functional exercise capacity of the individual ${ }^{14-17}$.

In view of the above, the objective of present study was to investigate the relationship between the distance covered in 6MWT and the length of hospital stay of patients admitted to Gaffrée e Guinle University Hospital wards.

\section{METHOD}

This is a cross-sectional study, which used a convenience sample, composed of patients admitted to Gaffrée Guinle University Hospital wards. The period of study was from October 2014 to November 2015. All patients underwent anamnesis and previous physical examination, in order to identify inclusion or exclusion criteria of the subjects.

All participants were volunteers and signed the Consent Form. The study was approved by the Research Ethics Committee of Federal Institute of Education, Science and Technology of Rio de Janeiro under number CAAE 42938715.0.0000.5268 according to Resolution 466/12 of the National Health Council in Brazil. 
The 6MWT was performed with patients aged over 18 years, between 2 and 7 days of hospitalization, with hemodynamic stability (systolic blood pressure between 100-140 mmHg, diastolic blood pressure between 60-100 $\mathrm{mmHg}$ and heart rate - HR between 60-100 bpm) and able to walk.

The patients with nausea, cardiac arrhythmias, decompensated COPD, severe cardiac disease (NYHA class IV), dyspnea at rest (MRC IV), hemodynamic instability, unstable angina, acute myocardial infarction in the previous month, deep venous thrombosis, central and/or peripheral neurological diseases, contact precaution and respiratory isolation were excluded from study. Other exclusion criteria for 6MWT were patients who refused to walk or presented cognitive alterations, intermittent claudication, orthopedic alterations of lower limbs leading to pain, use of orthoses or reduced visual and/or auditory acuity, conditions that might compromise exercise performance during 6MWT.

\section{Six-minute walk test (6MWT)}

The 6MWT was performed indoor, along a long, flat, straight, enclosed corridor, with a flat and hard surface, using standardized verbal command ${ }^{3}$. The walking course was 25 meter in length. Before the 6MWT, it was measured the following parameters: $\mathrm{HR}$ and peripheral oxygen saturation $\left(\mathrm{SpO}_{2}\right)$, through pulse oximetry (Onyx $9500^{\circledR}$ Nonin Medical - Minneapolis - Minnesota - USA), respiratory rate (RR), and subjective perception of effort, assessed by 
the Borg scale. The criteria for interrupting the test were: chest pain, intolerant dyspnea, lower limb muscle cramps, dizziness, cold sweats, as well as pallor and/or cyanosis and the individual's request. $\mathrm{HR}, \mathrm{SpO}_{2}$ and subjective perception of effort were checked at every two minutes during the 6MWT and in the first, second and third minutes of recovery.

Three measurements were performed during the first three minutes of recovery ( $1^{\text {st }} M R, 2^{\text {nd }} M R$, and $\left.3^{\text {rd }} M R\right)$. After thirty minutes of the first 6MWT, patients were invited to perform a second test, being considered for the analysis the longest distance covered.

In order to determine the predicted 6MWT distance (6MWTD), the following equation proposed by Brito et al. for the Brazilian population ${ }^{18}$ was used: [6MWTD $=890.46$ (6.11xage $)+(0.0345 x a g e 2)+(48.87 x g e n d e r)-(4.87 x b o d y$ mass index), being gender $=1$ (males) and gender $=0$ (females)].

\section{Statistical analysis}

The data were tabulated in a spreadsheet for further analysis in statistical package. Numerical variables were presented as mean \pm standard deviation and categorical variables were presented as percentages. The KolmogorovSmirnov test with Lilliefors' corrections was used to test for normality of data. The correlation between 6MWTD and the length of hospital stay was calculated by Pearson's correlation. A $p<0.05$ was considered significant. Statistical analyzes were performed using the statistical package and 
GraphPad Prism 5.0 (GraphPad Software, San Diego California USA).

\section{RESULTS}

A 78 patients were recruited, and 23 remained in study as shown in Figure 1, with 12 men (52\%) and 11 women $(48 \%)$, mean age $58.0 \pm 7.0$ years, weight $68.1 \pm 7.7 \mathrm{~kg}$, height $1.67 \pm 0.15$; and BMI of $23 \pm 0.3 \mathrm{~kg} / \mathrm{m}^{2}$. The reasons for hospital admission were $47.8 \%$ neoplasms, $20 \%$ gastrointestinal diseases, $19.5 \%$ pulmonary diseases and $12.7 \%$ cardiovascular diseases. The associated comorbidities are described in Table 1.

Figure 1. Distribution of the sample regarding included and excluded patients from the study with their respective causes.

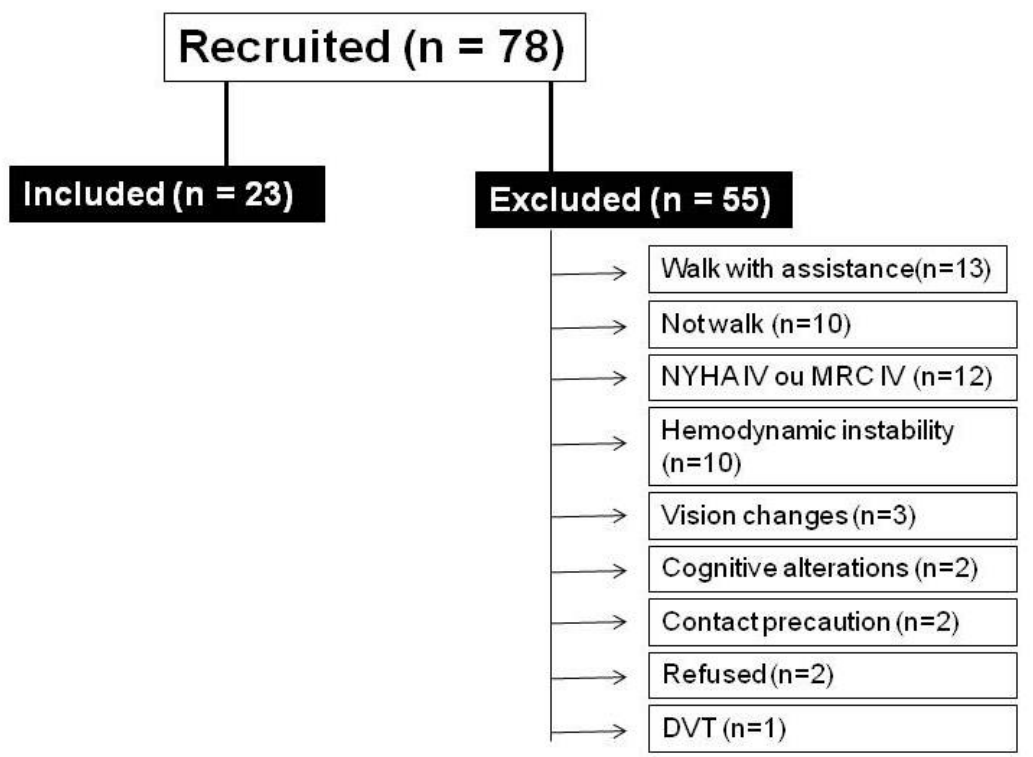

NYHA - New York Heart Association; MRC - Medical Research Council; DVT - deep vein thrombosis. 
Table 1. Sample distribution for comorbidities associated with reasons for hospitalization.

\begin{tabular}{lc}
\hline Associated comorbities & (\%) \\
\hline Cardiovascular & 50.0 \\
Metabolic & 10.1 \\
Rheumatology & 5.2 \\
Psychological & 5.0 \\
Hepatic & 2.5 \\
Renal & 2.5 \\
Not reported & 24.7 \\
\hline
\end{tabular}

The average time of hospitalization of the components of the sample was $12.4 \pm 5.6$ days. As far as the 6MWT goes, all patients completed it without complications. The average distance walked by the patients was $406.0 \pm 55.8$ meters and the median of the subjective sensation of effort at the end of the test was $5(\min =1 ; \max =7)$. The behavior of the hemodynamic and respiratory variables are described in Table 2. There was a significant difference between the values predicted and obtained for the distance covered in the 6MWT as shown in Figure 2.

Table 2. Behavior of the hemodynamic and respiratory variables of the sample components before, at the end and during the recovery of the six-minute walk test.

\begin{tabular}{lccccc}
\hline Variables & Rest & Final & $\mathbf{1}^{\text {st }}$ MR & $\mathbf{2}^{\text {nd }}$ MR & $3^{\text {rd }}$ MR \\
\hline SBP $(\mathrm{mmHg})$ & $122.0 \pm 7.9$ & $131.0 \pm 1605$ & $125.0 \pm 14.0$ & $122.0 \pm 12.0$ & $120.0 \pm 13.0$ \\
$\mathrm{DBP}(\mathrm{mmHg})$ & $76.7 \pm 9.8$ & $77.0 \pm 11.3$ & $77.0 \pm 11.5$ & $74.0 \pm 9.0$ & $73.4 \pm 9.2$ \\
$\mathrm{HR}(\mathrm{bpm})$ & $83.0 \pm 12.1$ & $97.0 \pm 19.4$ & $90.0 \pm 14.6$ & $89.0 \pm 11.9$ & $86.0 \pm 11.0$ \\
$\mathrm{RF}(\mathrm{irpm})$ & $19.0 \pm 4.0$ & $23.8 \pm 3,9$ & $21.2 \pm 4.4$ & $20 \pm 3.6$ & $19 \pm 3.5$ \\
$\mathrm{SpO}_{2}$ & $97.0 \pm 1.8$ & $95 \pm 2.1$ & $97.0 \pm 1.3$ & $97.0 \pm 1.1$ & $97.0 \pm 1.4$ \\
\hline
\end{tabular}

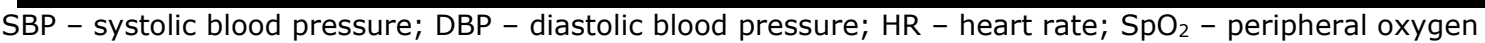
saturation; RF - respiratory frequency. 
Figure 2. Comparison between the values obtained and predicted for distance covered in the six-minute walk test (6MWD).

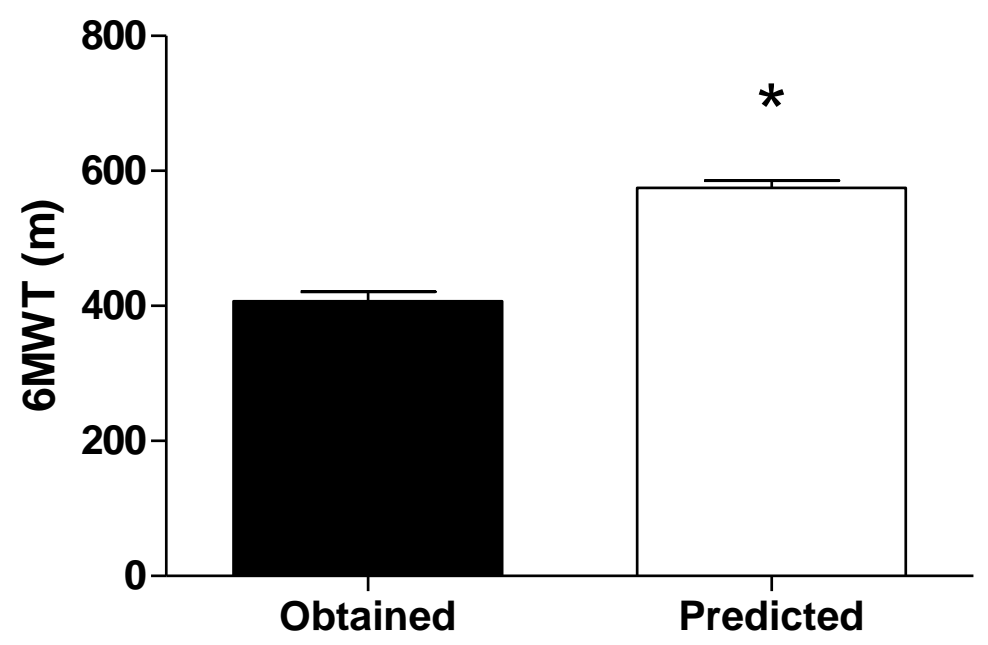

$* \mathrm{p}<0.0001$.

We observed that there was an association between the distance covered and the length of hospital stay for the sample analyzed, as observed in Figure 3.

Figure 3. Correlation between distance covered in the six-minute walk test (6MWD) and length of hospital stay.

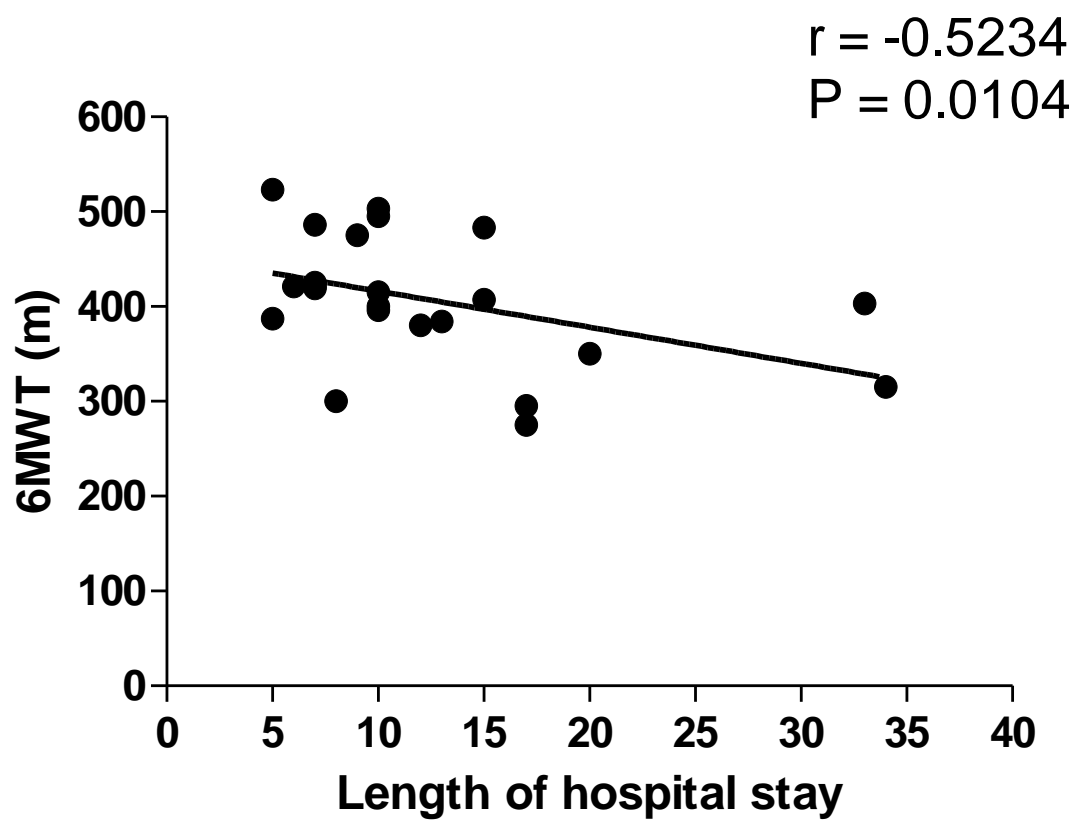




\section{DISCUSSION}

In the present study we aimed to evaluate the association between the distance covered in the 6MWT and the length of hospital stay in patients hospitalized in a ward. Our results point to a significant association, but it should be emphasized that the participants present a great variety of pathologies and causes of hospitalization, which makes the sample heterogeneous, differing from other studies that performed similar research in specific populations ${ }^{19}$.

The capacity of ambulation is described as the most complex function to be performed by the individual since it involves cardiovascular, respiratory, neural, musculoskeletal, proprioceptive responses and represents the individual's FA more adequately ${ }^{20}$.

Hospital admission can lead to physical deconditioning and also immobilism. In our study, we observed that the patients evaluated had an average hospitalization time of approximately two weeks. This period is described in the literature as being sufficient for alterations in the musculoskeletal system and may negatively influence the $\mathrm{FA}^{21}$ and therefore in the 6MWT.

In addition to the musculoskeletal changes that may have been acquired, part of the sample components of our study had as cause of hospitalization and/or comorbidities, cardiovascular or pulmonary diseases. The literature describes these changes as being a formal indication for the 6MWT, since the distance traveled may bring valuable 
information regarding not only the functional evaluation, but also the prognosis 3 3, 22-25.

According to Teodorczyk et $\mathrm{al}^{26}$ who evaluated $243 \mathrm{HF}$ patients on an outpatient basis, those who traveled distances less than 468 meters had a higher rate of hospitalization and mortality of $54 \%$ and $16 \%$, respectively, in the first year of follow-up.

In patients with COPD, Spruit et $\mathrm{al}^{27}$ evaluated 2110 patients and followed them for 3 years. Those who obtained walked distance on the 6MWT less than 334 meters had higher mortality rates and the ones who traveled distances less than 357 meters, the most frequent episode was hospitalization, when compared to patients who obtained higher ones.

We can infer that these factors may be responsible for the participant patients in our study to walk less than expected, on the 6MWT, since $32.2 \%$ had cardiovascular or pulmonary diseases as a reason for hospitalization and $50 \%$ had cardiovascular diseases as associated comorbidity.

Studies that have correlated exercise tests that measure FA with hospitalization time are scarce, especially with a sample as heterogenous as that of our study. De Buyser et $\mathrm{al}^{10}$ conducted a multicenter study with elderly patients admitted to hospital wards and had as objective to identify risk factors observed at admission that could predict institutionalization, hospitalization time and mortality, however, the tool used as exercise test was not the 6MWT, but the speed test of four meters. 
Oliveira et al ${ }^{19}$ investigated the association between HR and time of hospitalization using the 6MWT in 18 individuals undergoing cardiac surgery, where they were evaluated through spirometry and the 6MWT. The authors did not find a correlation between spirometry values and hospitalization time ( $r=0.07$ and $p=0.7790)$, only the distance walked on the 6MWT showed a correlation $(r=-0.62$ and $p=0.0058)$ with an average hospitalization time of $7.2 \pm 3.0$ days and D6MWT of $375.7 \pm 50.6$ meters. Such distance was lower than the one walked by the participants of our study, however, the hospitalization time we observed was higher than the authors did. It is worth mentioning that although the study objectives are similar, the population profile is quite different, being one of the factors that could explain the lower association found in our study $(r=-0.38$ and $p=0.0016)$ when compared to the authors' $(r=-0.62$ and $p=0.0058)$.

This study used a 25-meter corridor to perform the 6MWT, being lower than that recommended by the ATS ${ }^{3}$. The suggestion is that the size of the corridor could influence the distance covered in the 6MWT, however, in the hospital where the survey was conducted, no site was found ${ }^{22}$.

Another limitation was the heterogeneous sample with regard to pathologies, but in the wards, when they are not specialized, this is the reality found in the most diverse hospitals in the national territory. 


\section{CONCLUSION}

Through the present study we can observe that there is an association between the distance found in the six-minute walk test and the length of hospital stay. We suggest that further studies can be carried out so that we can elucidate these issues in a hospital setting.

\section{REFERENCES}

1. Costa R, Tereza E. Fatores determinantes da capacidade funcional entre idosos. Rev Saúde Pública 2003;37:40-8.

http://dx.doi.org/10.1590/S0034-89102003000100008

2.Gulart AA, Santos K, Munari AB, Karloh M, Cani KC, Mayer AF. Relação entre a capacidade funcional e a percepção de limitação em atividades de vida diária de pacientes com DPOC. Fisioter Pesq 2015;22:104-11. http://dx.doi.org/10.590/18092950/12836522022015

3.ATS Committee on Proficiency Standards for Clinical Pulmonary Function Laboratories. ATS statement: guidelines for the sixminute walk test. Am J Respir Crit Care Med 2002;166:111-7. http://dx.doi.org/10.1164/ajrccm.166.1.at1102

4.Carter R, Holiday DB, Nwasuruba C, Stocks J, Grothues C, Tiep B. 6minute walk work for assessment of functional capacity in patients with COPD. Chest 2003;123:1408-15.

http://dx.doi.org/10.1378/chest.123.5.1408

5. Morales-Blanhir JE, Palafox-Vidal CD, Rosas-Romero MJ, GarcíaCastro MM, Londoño-Villegas A, Zamboni M. Six-minute walk test: a valuable tool for assessing pulmonary impairment. J Bras Pneumol 2011;37:110-17. http://dx.doi.org/10.1590/S1806-

37132011000100016

6. Holland AE, Spruit MA, Troosters T, Puhan MA, Pepin V, Saey D, et al. An official European Respiratory Society/ American Thoracic Society Technical Standard: field walking tests in chronic respiratory disease. Eur Respir J 2014;44:1428-46. http://dx.doi.org/10.1183/09031936.00150314

7.Tabata M, Shimizu R, Kamekawa D, Kato M, Kamiya K, Akiyama A, et al. Six-minute walk distance is an independent predictor of hospital readmission in patients with chronic heart failure. Int Heart J 2014;55:331-6. http://dx.doi.org/10.1536/IHJ.13-224

8.Sant Anna M Jr. Six Minute Walk Test: Functional Evaluation and Prognosis in Heart Failure. J Nov Physiother Phys Rehabil 2015;2:69. http://dx.doi.org/10.17352/2455-5487.000028 
9. Oliveira EK, Da Silva VZM, Turquetto ALR. Relação do teste de caminhada pós-operatório e função pulmonar com o tempo de internação da cirurgia cardíaca. Rev Bras Cir Cardiovasc 2009;24:47884. http://dx.doi.org/10.1590/S0102-76382009000500008

10.De Buyser SL, Petrovic M, Taes YE, Vetrano DL, Onder G. A Multicomponent Approach to Identify Predictors of Hospital Outcomes in Older In-Patients: A Multicentre, Observational Study. PLoS One 2014;9:e115413. http://dx.doi.org/10.1371/journal.pone.0115413

11. Killewich LA. Strategies to minimize postoperative deconditioning in elderly surgical patients. J Am Coll Surg 2006;203:73545. http://dx.doi.org/10.1016/j.jamcollsurg.2006.07.012

12. Hirschhorn AD, Richards D, Mungovan SF, Morris NR, Adams L. Supervised moderate intensity exercise imporves distance walked at hospital discharge following coronary artery bypass graft surgery: a randomised controlled trial. Heart Lung Circ 2008;17:129-38. http://dx.doi.org/10.1016/j.hlc.2007.-9.004

13. Whelan HBSA. Addressing Senior Immobility And Functional Decline During Hospitalization In Ontario. University of Ottawa J Med 2015;5:26-8.

https://pdfs.semanticscholar.org/5af1/3e1ea8c31a40953fc239fea9a4 1172c66176.pdf

14. Bellinetti LM, Thomson JC. Respiratory muscle evaluation in elective thoracotomies and laparotomies of the upper abdomen. J Bras Pneumol 2006;32:99-105. http://dx.doi.org/10.1590/s180637132006000200004

15. Macchi C, Fattirolli F, Lova RM, Conti AA, Luisi ML, Intini R, et al. Early and Late Rehabilitation and Physical Training in Elderly Patients After Cardiac Surgery. Am J Phys Med Rehabil 2007;86:826-34. http://dx.doi.org/10.1097/PHM.0b013e318151fd86

16. Andrade TM, Alves ELM, Figueiredo MLF, Batista MEM, Alves CMS. Evaluation of functional capacity of elderly through the test of sixminute walk. J Res Fundam Care 2015;7:2042-50. http://dx.doi.org/10.9789/2175-5361.2015.v7i1.2042-2050

17.Fassbinder TRC, Winkelmann ER, Shneider J, Wendland J, Oliveira $O B$. Capacidade funcional e qualidade de vida de pacientes com doença renal crônica pré-dialítica e em hemodiálise - Um estudo transversal. J Bras Nefrol 2015;37:47-54. http://dx.doi.org/10.5935/01012800.20150008

18. Britto RR, Probst VS, Andrade AFD, Samora GAR, Hernandes NA, Marinho PEM, et al. Reference equations for the six-minute walk distance based on a Brazilian multicenter study. Braz J Phys Ther 2013; 17:556-63.

http://dx.doi.org/10.1590/S1413-

35552012005000122

19. Oliveira EK, Da Silva VZM, Turquetto ALR. Relação do teste de caminhada pós-operatório e função pulmonar com o tempo de internação da cirurgia cardíaca. Rev Bras Cir Cardiovasc 2009;24:47884. http://dx.doi.org/10.1590/S0102-76382009000500008

20. Bellinetti LM, Thomson JC. Respiratory muscle evaluation in elective thoracotomies and laparotomies of the upper abdomen. J Bras Pneumol 
21.Kho ME, Truong AD, Brower RG, Palmer JB, Fan E, Zanni JM, et al. Neuromuscular electrical stimulation for intensive care unit-acquired weakness: protocol and methodological implications for a randomized, sham-controlled, phase II trial. Phys Ther 2012;92:156479. http://dx.doi.org/10.2522/ptj.20110437

22. Morales-Blanhir JE, Vidal CDP, Romero MJR, Castro MMG, Villegas $A L$, Zamboni M. Six-minute walk test: a valuable tool for assessing pulmonary impairment. J Bras Pneumol 2011;37:110-17. http://dx.doi.org/10.1590/S1806-37132011000100016

23.Celli BR, Locantore N, Yates J, Tal-Singer R, Miller BE, Bakke $\mathrm{P}$, et al. Inflammatory Biomarkers Improve Clinical Prediction of Mortality in Chronic Obstructive Pulmonary Disease. Am J Respir Crit Care Med 2012;185:1065-72. http://dx.doi.org/10.1164/rccm.201110$17920 \mathrm{C}$

24.Polkey MI, Spruit MA, Edwards LD, Watkins ML, Pinto-Plata $\mathrm{V}$, Vestbo J, et al. Six-minute-walk test in chronic obstructive pulmonary disease: minimal clinically important difference for death or hospitalization. Am J Respir Crit Care Med 2013;187:382-6. http://dx.doi.org/10.1164/rccm.201209$15960 \mathrm{C}$

25.Andrianopoulos $V$, wouters EF, Pinto-Plata VM, Vanfleteren LE, Bakke PS, Franssen FM, et al. Prognostic value of variables derived from the sixminute walk test in patients with COPD: Results from the ECLIPSE study. Respir Med 2015;109:1138-46. http://dx.doi.org/10.1016/j.rmed.2015.06.013 26.Wegrzynowska-Teodorczyk K, Rudzinska E, Lazorczyk M, Nowakowska K, Banasiak W, Ponikowski P, Wozniewski M, et al. Distance covered during a six-minute walk test predicts long-term cardiovascular mortality and hospitalization rates in men with systolic heart failure: an observational study. J Physiother 2013;59:177-87. http://dx.doi.org/10.1016/S1836-9553(13)70182-6

27.Spruit MA, Polkey MI, Celli B, Edwards LD, Watkins ML, Pinto-Plata $\mathrm{V}$, et al. Predicting outcomes from 6-minute walk distance in chronic obstructive pulmonary disease. J Am Med Dir Assoc 2012;13:291-7. http://dx.doi.org/10.1016/j.jamda.2011.06.009 